\title{
「交流可変速ドライブの産業応用 特集号」の編集に寄せて
}

\author{
特集号編集担当
}

正員深 尾正 (柬京工賞大学工学部)

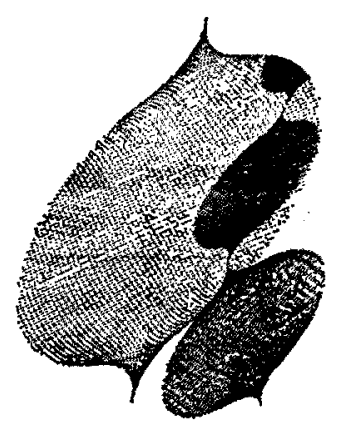

交流電動機の可変速駆動技術は，半導体素子とその 応用技術，制御理論とこれを実際のシステムへ導入す るととを可能にした LSI，マイクロプロセッサなどの 回路技術，ソフトウェア技術の進歩によって，目ざま しい発展を遂げた。その発展の大きな要因として, 大 学や企業で行われているてれらの分野の研究, 開発の 成果が, 学会誌や学会の大会, 国際会議などで活発に 発表され，库学互いの技衡レベルの向上を促したてと が挙げられよう。

電気学会全国大会のこの分野の発表論文件数を見る と, 昭和 60 年, 61 年には電動機制御だけで 1 分冊に なっており，約 100 件の発表がされている。他の分冊 の関連の発表や学会誌, 国際会議, 企業の技報の論 文など, 容易に入手できる文献だけであおてらく年間 200 件以上になるであろう。

一方，乙の分野の発展のもう一つの要因として，い ち早くこれらの技術が, 金属, 化学, 維維業, 電 力, 交通, 公共事業加家電品にまで皘極的に採用さ れたととが指摘される。しかしながら，電気学会諭文 誌の論文には, 新規性, 独創性が要求されていたため 原理, 基本構成などの理論, 解析が中心の論文が主 で，応用面を取上げた論文はほとんどなかった。

交流電動機の可変速駆動技術の一層の発展には新方 式の提案, 原理や基本構成などの理論的な検討と共 に，応用にあたっての技術的な課題，使用条件を满足 させるための工夫, 利用者側からの使用実績の報告や 問題点の指摘，あるいは要求などが公開の場に提出さ れ，議論されて研究，開発に反映されることがぜひと あ必要である。

産業応用部門誌の使命の一つは, 従来は企業の技報 などでもっばら取上げられていた応用面に焦点をあて た論文にも捍載の場を作り，広く会員に有用な情報を 提供することにあると考える。

その意味で，産業応用部門認の第 2 号の特集テーマ として「交流可変速ドライブの産業応用」を取上げ
た。しかし，特集号と言ってあ論文誌である以上，特 集号編集担当者の意図化従って特定の著者住定の記 事の執筆をお願いし揭載するわけにはいかない。従来 の一般論文と同様，会員の方から自主的に投稿してい ただいた原稿の中から、論文委員の查読を経て探録が 決定された論文のみが揭載されるのであるから，解説 記事のように，一貫した筋を通すととはできないのは あちろんである。

従って，今回特集号に投稿していただき，採録にな った 9 件の論文の中には必ずしす「産業応用」には直 接には触れられていないあのもあるが，で筧いただく とおり, 压延機駆動用の大容量, 高性能の誘導機ある いは同期機駆動システムやこれらの比較などに関する すの 3 件，実用的な観点加ら制御電圧源，制御電流源 ベクトル制御の性能を比較したもの，センサレスでク トル制御汇関するあの 2 件, ディジタルシグナルプロ セッサの適用汇関するすの 2 件、ベクトル制御の最適 化㳊関するあのなど，特集号の主旨にかなった有用な 論文が取上げられたと確信している。

今後とあ，豊富な普遍性のあるデータと客観的な評 価が明らかな論文を特にユーザの方々から期待した W。

本号では，ほ加に従来ど扔りの一般論文はすちろ ん, 交流可変速駆動に関係の深い電気学会の調査研究 專門委員会の活動状況の報告，新しい試みとしててれ から交流可変速の研究を始め上うとする方々への文献 稆介の記事, 誘導電動機の発明 100 年を記念してイタ リアで開かれた国際会議の報告などが掲載されてい 万。

会員の皆様に特集論文，一般論文と共にこれらの特 集号に関する記事が抢役にたてば幸いである。

ぜひ，本号のてれらの記事に対する北評，意見ある いは産業态用部門誌に対する提案など，会員の声欄に お寄せいただきたい。

(昭和 61 年 12 月 16 日受付) 